Discussion Paper No. 956

\title{
GENDER WAGE GAP AND ITS EFFECT ON TEST SCORES OF IMMIGRANT STUDENTS
}

\author{
Eiji Yamamura
}

February 2016

The Institute of Social and Economic Research Osaka University

6-1 Mihogaoka, Ibaraki, Osaka 567-0047, Japan 


\title{
Gender Wage Gap and its Effect on Test Scores of Immigrant Students
}

\author{
Eiji Yamamura
}

Department of Economics, Seinan Gakuin University

6-2-92 Sawara-ku, Nishijin, Fukuoka 814-8511, Japan

Tel: +81-(0)92-823-4543, Fax: +81-(0)92-823-2506, E-mail: yamaei@seinan-gu.ac.jp

\begin{abstract}
This paper examines how gender equality influences difference in cognitive skills between genders. For closer examination of Guiso et al. (2008), restricting the sample to immigrant allows us to reduce the possibility of reverse causality. Key findings obtained through regression estimation are: (1) decreased gender wage gap leads to girls exhibiting a reduced incidence of lateness and skipping school compared with boys, which in turn improves girls' test scores in mathematics, science, and reading; (2) the direct effect of the decreased wage gap on test scores exceeds its indirect effect on performance owing to influencing school attendance. Considering the direct and indirect effects of the wage gap: each $1 \%$ decrease in the wage gap results in a $0.20 \%, 0.13 \%$ or $0.06 \%$ increase in test scores for mathematics, science, and reading, respectively.
\end{abstract}

Keywords: Gender gap index, Test scores, Mathematics, Immigrants.

JEL classification: D81, O11; Q54; Z13 


\section{Introduction}

The gender wage gap is a critical issue for both academic researchers and policy makers to consider (World Economic Forum 2011). The gender wage gap is widely observed and so has been formally studied (Bartolucci 2013). One potential explanation for the gender wage gap is that it might reflect differences in cognitive skills. In fact, a gender gap exists in educational achievement, for example as measured by school test scores (e.g., Dee 2007; Goldin et al. 2008; Cornwell et al. 2013; Stoet and Geary 2013; Fortin et al., 2015). Graduates with higher test scores in mathematics are observed to attain a higher educational level and earn higher income than others (e.g., Altonji 1995; Levine and Zimmerman 1995; Rose and Betts 2004; Joensen and Nielsen 2009). Girls’ scores in mathematics are also observed to be lower than those of boys (Guiso et al., 2008; Fryer and Levitt 2010; Stoet and Geary 2013). Relative lack of mathematical skills among girls is thought to be one of the factors supporting the gender wage gap. Economic incentives are thought to play an important role in learning and hence in improving cognitive skills ${ }^{1}$. Many researchers have attempted to empirically examine the economic incentives associated with educational achievement (Angrist and Lavy 2009; Kremer et al. 2009; Leuven et al. 2010; Fryer 2011; Bettinger 2012; Angrist et al. 2014). Increasing numbers of researchers have focused on the gender gap in mathematics and its relationship with empirical economics (e.g., Ellison and Swanson 2010; Guiso et al. 2008; Fryer and Levitt 2010; Niederle and Versterlund 2010).

Existing studies used PISA data to consider the effects of social conditions on the gender gap in mathematics test scores (Guiso et al. 2008; Fryer and Levitt 2010; Stoet and Geary 2013) ${ }^{2}$. However, the key variable used in these papers was the Gender Gap Index (GGI) sourced from the World Economic Forum's Global Gender Index (WEF-GGI). The GGI comprises various gender gaps, such as economic, political empowerment, health status and so on. Therefore, these studies did not scrutinize whether economic conditions influenced the gender gap in test scores by creating an

\footnotetext{
1 Gneezy and Rustichini (2000) pointed out the possibility that extrinsic rewards can crowd out intrinsic motivation.

2 PISA data are widely used for empirical study in the social sciences (e.g., Fuchs and Woessmann 2007; Sprietsma 2010; Gamboa and Waltenberg 2012; Ammermueller 2013; Hanushek et al. 2013).
} 
incentive to learn. From the viewpoint of economics, it is valuable to specifically investigate the economic gender gap that relates to girls' incentives to study. Adult females are a role model for female students, and can motivate girls to study and otherwise influence their behavior (Neumark and Gardecki 1998; Bettinger and Long 2005). Female students have a particular incentive to learn and improve their test scores when academic achievement is positively related to wage level. When motivated by the expectation of higher female wage levels in future, female students make more effort to learn during class. Therefore, girls' test scores vary with adult female wage levels even given identical time spent learning at school. Furthermore, an expectation of higher female wages in future means that female students have a motivation to regularly attend school and that their parents have a motivation to direct their daughters to attend school. This, in turn, improves test score.

To explore the channels through which female students can improve their test scores, this paper investigates both the direct effect of gender wage gap on test scores and the indirect effect it exerts through influencing school attendance. The direct effect can be considered to involve quality of classroom learning, while the indirect effect can be considered to involve quantity of learning time at school. Further, the samples of existing works have included fewer than 50 countries (Guiso et al. 2008; Fryer and Levitt 2010). However, the number of countries included in PISA 2012 increased and so 62 countries are used for estimation in this study. This improves the accuracy of the estimation results. Existing studies consider the influence of social conditions on test scores in mathematics and reading (Fryer and Levitt 2010; Stoet and Geary 2013). From PISA 2012 we can obtain not only mathematics and reading test scores, but also science test scores. So this paper compares the effects of the gender wage gap on test scores among three subjects. Females' higher academic skills is thought to lead to the higher marginal productivity. If so, Causality between the gender wage gap and the gender gap in test scores is ambiguous, resulting in estimation bias. For immigrant student, female's wage level is exogenously given. To identify the effect of the gender wage gap, our sample is restricted to immigrant students. The key findings of this paper are that decreased gender wage gap not only improves test scores in mathematics but also in science and reading. This holds true especially when considering indirect effects on the performance of female students, such as truancy reducing wages. However, the effect of 
decreased wage gap on the test scores of female students is larger for mathematics than for science and mathematics.

This paper organized as follows: section II describes the data, section III presents the econometric specifications, section IV presents the estimation results and section V concludes.

\section{Data}

Concerning individual level data, I use data from PISA, a triennial worldwide test of academic achievement among 15 year olds conducted since 2000. The Organization for Economic Co-operation and Development (OECD) coordinates the implementation of PISA. The PISA test conducted in 2012 assessed three subjects, namely mathematics, science knowledge and reading literacy. Over 485,000 students from 68 countries took the PISA test in 2012. WEF-GGI provided the data on the gender gap in modern society. Especially, this paper focused on the wage gap between males and females from an economic viewpoint. Following the method of Guiso et al. (2008) and Fryer and Levitt (2010), PISA 2012 data are matched with WEF-GGI 2011 data to examine the association of the gender gap with academic test score. In previous works (Guiso et al. 2008; Fryer and Levitt 2010) national average PISA data are matched with WEF-GGI data. In contrast, in this paper, individual level PISA data are matched with country level WEF-GGI data, which allows controlling for individual level characteristics of students. As is exhibited in Table A1, among 68 countries, 63 are used for estimations because WEF-GGI data cannot be obtained for five countries. In comparison with PISA 2003, which provided the data for previous works (Guiso et al. 2008; Fryer and Levitt 2010), the number of countries participating in PISA 2012 increased to 68 (PISA 2012), from 41 previously. Fryer and Levitt (2010) argued that estimation results changed when the sample was restricted to that of "TIMSS (Trends in International Mathematics and Science Study)-PISA overlap”. To check the robustness of the estimation results, this paper also used subsamples of countries equivalent to the “TIMSS-PISA overlap” samples. Reverse causality seems to exist between the gender wage gap and gender test score gap because well-educated females can find work that pays high wages. To reduce the possibility of reverse causality, this paper restricted the 
sample to students who were migrants from other countries because students were unlikely to have been the decision-makers regarding immigration and so the gender wage gap of their country of residence was, to a certain extent, exogenously given. Consequently, the sample size reduced to about 19,000 individuals in the baseline model, representing 62 countries $^{3}$.

\section{Econometric Specification}

The variables used in the regression estimations are shown in Table 1, which indicates definitions and basic statistics (mean and standard deviation). The estimated function of the baseline model takes the following form:

$$
\begin{aligned}
& Y_{i m}=\alpha_{0}+\alpha_{1} W A G E_{-} F M_{\mathrm{m}} * F E M A L E_{i}+\alpha_{2} W A G E_{-} F M_{\mathrm{m}}+\alpha_{3} F E M A L E_{i}+\alpha_{4} L N(G D P)_{\mathrm{m}}+ \\
& \alpha_{5} L A T E_{\mathrm{im}}+\alpha_{6} S K I P_{\mathrm{im}}+\alpha_{7} A G E_{\mathrm{im}}+\alpha_{8} A R \_A G E_{\mathrm{im}}+\alpha_{9} W E A L T H_{\mathrm{im}}+\alpha_{10} H_{-} F A T H_{\mathrm{im}}+ \\
& \alpha_{11} H_{-} M O T H_{\mathrm{im}}+\alpha_{12} H_{-} B R O T H_{\mathrm{im}}+\alpha_{13} H_{-} S I S T E_{\mathrm{im}}+X^{\prime} B+\mathrm{u}_{\mathrm{im}},
\end{aligned}
$$

where $Y_{i m}$ represents the dependent variable for individual $i$ and country $m$. $Y_{i m}$ are student's test scores (MATH, SCIE, and READ), which take the log form for convenience of interpretation. Regression parameters are represented by $\alpha$. The error term is represented by $\mathrm{u}_{\mathrm{im}}$. Furthermore, disturbances in the equation when $M A T H$ is a dependent variable may correlate with disturbances when SCIE (and also READ) is a dependent variable. Hence, MATH, SCIE, and $R E A D$ should be jointly estimated because of correlations between disturbances. In this case, a seemingly unrelated regression model (SUR) is preferred. Hence, I used an SUR model for the estimations. $X$ is a vector of other control variables such as parental educational level, and number of books in the home. $B$ is a vector of the coefficients of national and individual characteristics.

Gender difference among students and gender gap in economic status are captured by including FEMALE (female dummy) and WAGE_FM (female wage/male wage), respectively. We see from Table 1 that the mean value of $W A G E_{-} F M$ is 0.65 , which implies that the average wage level of female adults is around $65 \%$ that of male adults. The key variable of this paper is, $W A G E \_F M * F E M A L E$ (the cross term of WAGE_FM and FEMALE). If female wage increases relative to male wage, and as a result the test scores of female students increase relative to those

3 The estimation results using the full sample (including non-immigrant students) are almost the same as those reported in this paper. The results are available from the author upon request. 
of male students, then $W A G E_{-} F M *$ FEMALE has a positive sign. To control for the level of economic development in students' country of residence, log of per capita GDP is included. To consider the effect of time spent on study in school on test score, LATE and SKIP are incorporated. Time spent on class is thought to be an input for educational achievement and so to be positively associated with test score. LATE and SKIP are considered to reduce the time spent and their coefficient sign is predicted to be negative.

Even within the group aged 15 years, the ages of individual students differ by months. PISA 2012 provides student age information not only in years but also in months, and so $A G E$ is included. Table 1 suggested that the mean value of $A G E$ is 15.7 years. This paper restricted the sample to students that had immigrated from other countries and so degree of assimilation is critical to academic achievement (Akresh and Redstone 2011, Nielsen and Rangvid 2012). The timing of arrival in the country of residence is thought to reflect academic performance, especially for reading scores because reading experience increases with the time students have spent living in a given language environment. $A R_{-} A G E$ (age of arrival in the country of residence) is included and its expected coefficient sign is negative. As shown in Table 1, the mean value of $A R \_A G E$ is 6.4 , which is almost the starting year of primary school although the educational system differs with country. For the 2012 data, an average of 9 years had passed since the arrival of students at their country of residence from their country of birth. Concerning family characteristics, PISA 2012 provides information about WEALTH (family wealth) and so is incorporated to control for family economic status. Further, living with family members is observed to influence academic performance (Bettinger et al. 2014) and so H_FATH, H_MOTH, H_BROTH, and H_SISTE are included to capture this effect. As for other control variables, parental educational level and number of books in the home are included to represent family educational circumstance. Besides the baseline model (1), time spent on an each subject ( $S T U \_M A T H, S T U \_S C I E$, and STU_READ) can be obtained from PISA 2012 and so is included in the alternative model despite its sample size being reduced because the sample used for model (1) has many missing values for $S T U_{-} M A T H$, $S T U_{-} S C I E$, and $S T U_{-} R E A D$.

The previously suggested equation examines the direct effect of gender wage gap on test scores. Besides, the indirect effects of gender wage gap on test scores are examined, including through such mechanisms as lateness in coming to school and skipping school entirely. The method is as follows: in the first step, coefficients of LATE and SKIP are obtained in the previous estimations. In the second step, to assess the effect of gender wage gap on lateness for school and skipping school, LATE and SKIP are dependent variables when the same control variables used in equation (1), apart from LATE and 
SKIP, are included. The equation is:

$$
\begin{aligned}
& Z_{i m}=\beta_{0}+\beta_{1} W A G E_{-} F M_{\mathrm{m}} * F E M A L E_{i}+\beta_{2} W A G E_{-} F M_{\mathrm{m}}+\beta_{3} F E M A L E_{i}+\beta_{4} L N(G D P)_{\mathrm{m}}+ \\
& \beta_{5} A G E_{\mathrm{im}}+\beta_{6} A R \_A G E_{\mathrm{im}}+\beta_{7} W E A L T H_{\mathrm{im}}+\beta_{8} H_{-} F A T H_{\mathrm{im}}+\beta_{9} H_{-} M O T H_{\mathrm{im}}+\beta_{10} H_{-} B R O T H_{\mathrm{im}} \\
& +\beta_{11} H_{-} S I S T E_{\mathrm{im}}+X^{\prime} C+\mathrm{e}_{\mathrm{im}} \text {, }
\end{aligned}
$$

where $Z_{\text {im }}$ represents the dependent variable LATE (or SKIP ), which is censored at 1 , and so the Tobit model is appropriate. Further, disturbances in the equation when SKIP is a dependent variable may correlate with disturbances when $L A T E$ is a dependent variable. Both SKIP and LATE should be jointly estimated because of correlations between disturbances. In this case, a bivariate Trobit model is preferred and so is used in this paper. The key variable is the product of $W A G E \_F M * F E M A L E$. A higher education leads students to earn higher income (e.g., Altonji 1995; Levine and Zimmerman 1995; Rose and Betts 2004; Joensen and Nielsen 2009). If this holds, female wages increase relative to male wages, leading girls to regularly attend school to increase their probability of earning higher wages in the future. Therefore, the coefficient of $W A G E \_F M * F E M A L E$ is predicted to have a negative sign in equation (2).

Considering the results of equations (1) and (2) to estimate the indirect effect of gender wage gap on test scores via such mechanisms as being late for school and skipping school.

\section{Results}

Table 2 indicates the results of the mean difference test of test scores between boys and girls. Consistent with existing works (Guiso et al. 2008; Fryer and Levitt 2010; Stoet and Geary 2013), mean score for MATH is 11 points higher for boys than girls, with this difference being statistically significant at the $1 \%$ level. In contrast, mean scores for SCIE and READ are higher for girls than boys. With respect to READ, the difference is 39 points, and is statistically significant at the $1 \%$ level, which is in line with Fryer and Levitt (2010) and Stoet and Geary (2013). However, for SCIE, the difference is only 2 points, and is statistically significant at the $10 \%$ level. Thus the gender difference for SCIE is less clear than for MATH and READ.

Figures 1(a)-1(c) illustrated the relation between gender wage gap and gender gap in each test score, and are comparable to Figures 2 of Fryer and Levitt (2010). Similar to Figures 2 of Fryer and Levitt (2010), we observe positive relations between 
the gender wage gap and gender test score gap in Figures 1(a)-1(c). Hence, as gender wage gap decreases, the test scores of girls improve relative to those of boys. However, these figures exclude other factors. For closer examination of the relation, estimation based on individual-level data should be checked.

Now we turn to the results of regression estimations. Tales 3-5 report the estimation results of the SUR model, where $\operatorname{Ln}(M A T H), \operatorname{Ln}(S C I E)$ and $\operatorname{Ln}(R E A D)$ are dependent variables. In each Table, columns (1), (2) and (3) indicate results when $L n$ $(M A T H), \operatorname{Ln}(S C I E)$ and $\operatorname{Ln}(R E A D)$ are dependent variables, respectively. As for key variables, WAGE_FM * FEMALE shows a positive sign in columns (1) and (2), and is statistically significant. In contrast, WAGE_FM* FEMALE shows a negative sign in column (2), despite being statistically insignificant. These results imply that as the wage level of females approaches that of males, the test scores of female students in mathematics and science improve relative to those of male students. What is more, the absolute value of the coefficient of WAGE_FM * FEMALE is 0.13 for $\operatorname{Ln}(M A T H)$ and 0.07 for $\operatorname{Ln}(S C I E)$. This can be interpreted as suggesting that a $1 \%$ increase in the female-over-male wage ratio increases the mathematics test scores of female students by $0.13 \%$ relative to males, and increases the test scores for science by $0.07 \%$. However, such an effect is not observed for the reading test score. Concerning other key variables, both $L A T E$ and SKIP show negative signs and are statistically significant at the $1 \%$ level in columns (1)-(3). Therefore, absence from class reduces test score regardless of subject. Further, in all columns, the absolute values of LATE and SKIP are 0.01 and 0.02 , respectively. Specifically, the test score of all subjects deceases by $1 \%$ (2\%) when the frequency of being late for school (skipping school) deceases by 1 point on the 4 point scale.. That is, quantity of time spent in class contributes substantially to cognitive skills for all subjects. As for control variables, the coefficient of $A G E$ is significant and positive sign in all columns. Therefore, as students mature, their test scores for all subjects improve. After controlling for student age, it is interesting to observe that $A R \_A G E$ is statistically significant at the $1 \%$ level in columns (2) and (3) but not in column (1), although the sign of $A R \_A G E$ is negative in all columns. Furthermore, the absolute value of the coefficient of $A R \_A G E$ is 0.002 for reading, which is twice its value of 0.001 for science. This implies that for each one year decrease in the age of students' arrival in their country of residence there occurs a $0.02(0.01) \%$ increase in test scores for reading (science). Our interpretation of this result is that more experience of learning the language of the host country in daily life improves students' linguistic abilities, which are necessary for reading. Linguistic ability plays a role in understanding science, but is less important in understanding mathematics. In columns (1)-(3), $H_{-} F A T H$ and $H_{-} M O T H$ are significantly positive whereas 
H_BROTH and H_SISTE are significantly negative. Living with parents improves cognitive skills partly because parents take care of their children's daily life, which in turn improves academic performance. In contrast, the existence of siblings is considered to reduce educational quality because average spending on children's education decreases as the number of children increases. For robustness check, total minutes of class study on each subject are included as independent variables and the results are shown in Table 4 . We see from Table 4 that the coefficients of $S T U_{-} M A T H, S T U_{-} S C I E$, and $S T U_{-} R E A D$ are positive and statistically significant at the $1 \%$ level, suggesting that inputs for each subject increase the output (test score). Concerning other variables, the estimation results of Table 4 are almost identical to those of Table 3. Moreover, the estimation results of Table 3 are robust for alternative specifications. As pointed out by Fryer and Levitt (2010), the influences of females' social condition on test scores disappear when PISA data is restricted to countries that overlapped with the TIMSS data. For further robustness check, Table 5 reports the results based on the “TIMSS-PISA overlap” samples. The upper part of Table 5 shows the results based on a sub-sample of countries that are equivalent to the "TIMSS-PISA 2003 overlap" countries of Fryer and Levitt (2010). The number of countries included in PISA 2012 increased relative to PISA 2003, the data source for Fryer and Levitt (2010). Therefore, the lower part of Table 5 shows the results based on using a sub-sample of countries equivalent to the “TIMSS-PISA 2012 overlap” countries. In Table 5, a significant positive sign of WAGE_FM* FEMALE is persistently observed for mathematics, while for science it is not statistically significant. Turning to LATE and SKIP, both continue to show a significant negative sign for all subjects. All in all, restricting the analysis to a sub-sample does not influence the results, with the exception of the effect of $W A G E F M * F E M A L E$ on science score.

We now turn our attention to the estimation results of Table 6 when LATE and SKIP are dependent variables. We focus on the results for WAGE_FM*FEMALE, which is the key variable. Table 6 indicates the significant negative signs for LATE and SKIP. Further, the absolute values of the coefficients of LATE and SKIP are 1.04 and 1.98, respectively. This can be interpreted as suggesting that a $10 \%$ increase in female-over-male wage ratio results in a $0.198(0.104)$ point decrease, on the 4 point scale, in the frequency of skipping school (being late for school). To check robustness, we conduct the estimation on the sub-sample used in Table 5, and the results are presented in Table 7. In Table 7, WAGE_FM* FEMALE continues to show a significant negative sign for SKIP, whereas statistical 
significance of $W A G E_{-} F M *$ FEMALE is not observed for LATE despite it having a negative sign. The absolute value of the coefficient of $W A G E_{-} F M * F E M A L E$ increased to about 2.9 for SKIP, which is about three times larger than that reported in Table 6. The combined effect of WAGE_FM * FEMALE on LATE and SKIP is approximately 3.00 for Tables 6 and 7.

Existing works (Guiso et al., 2008; Fryer and Levitt 2010) only consider the direct effect of female social condition on the gender gap in test scores. Additionally, we provide estimations of the indirect effect of the gender wage gap on test scores through its effect on school attendance. Based on the results of Tables 3 and 6, we calculated the degree of the effects and its results are presented in Table 8. The direct effects of the decrease in gender wage gap are the coefficients of $W A G E \_F M * F E M A L E$ indicated in Table 3. The indirect effect of a $1 \%$ decrease in the wage gap is the coefficient of LATE (SKIP) multiplied by that of WAGE_FM $*$ FEMALE. The indirect effect of a $1 \%$ decrease in the wage gap through being late for school is $0.02 \%$ for all subjects, while the indirect effect through skipping school is $0.05 \%$ for mathematics and $0.04 \%$ for science and reading. What has been observed thus far reveals a distinct difference in the direct effect of gender wage gap among the three subjects while the indirect effect is almost the same for all subjects. Considering the direct and indirect effects together leads to a $1 \%$ decrease in the effect of the gender wage gap, resulting in it being $0.20 \%, 0.13 \%$ and $0.06 \%$ for mathematics, science and reading. Therefore, the total effect of the decrease in gender wage gap for mathematics is about 1.5 times larger than for science, and three times larger than for reading.

What has been observed thus far implies that the gender wage gap influences quantity of study, which improves test scores in the three subjects equally. However, after controlling for quantity of study, the gender wage gap improves skills in mathematics and sciences, but not in reading. So, the effect of gender wage gap on attitude toward learning during class is thought to vary according to subject.

\section{Conclusions}

This paper examines how the gender wage gap influences the test scores of female versus male students. Using PISA 2012 matched with the gender wage gap sourced from WEF-GGI 2011, we compare the effect of the wage gap among the areas of mathematics, science and reading. Key findings are that a decrease in the gender wage gap leads to a decrease in truancy by female students, which in turn improves the 
test scores of female students in mathematics, science, and reading. Even after controlling this channel, decrease in the gender wage gap improves the test scores of female students in mathematics and science, though not reading. Combining the indirect and direct effects of the gender wage gap: for female students, each $1 \%$ decrease in the wage gap relative to males leads to a $0.20 \%, 0.13 \%$ and $0.06 \%$ increase in test scores for mathematics, science and reading, respectively.

In comparison with the existing works of Guiso et al. (2008) and Fryer and Levitt (2010), the findings of this paper are more reliable because (1) analysis at the individual level lets us consider the effect of individual level characteristics, (2) the sample was restricted to child immigrants from other countries, reducing the possibility of reverse causality, (3) the countries included in the sample are larger. The findings of this paper made it evident that higher female wage level relative to male wage level incentivizes female students to attend school, resulting in their achieving higher test scores not only for mathematics, but also for science and reading.

\section{Acknowledgement: I will deeply thank Kunio Urakawa for providing the data and the discussion for this issue.}




\section{REFERENCES.}

Akresh, Richard and Redstone, Akresh, "Using Achievement Tests to Measure Language Assimilation and Language Bias among the Children of Immigrants,” Journal of Human Resources 46:3 (2011), 647-667.

Altonji, Joseph. "The Effect of High School Curriculum on Education and Labor Market Outcomes,” Journal of Human Resources 30:3 (1995), 409-438.

Ammermueller, ,Andreas. “Institutional Features of Schooling Systems and Educational Inequality: Cross - Country Evidence From PIRLS and PISA,” German Economic Review 14:2 (2013), 190-213.

Angrist, Joshua., Philip Oreopoulos., and Tyler Williams. "When Opportunity Knocks, Who Answers?: New Evidence on College Achievement Awards,“ Journal of Human Resources 49:3 (2014), 572-610.

--------., and Victor Lavy,. "The Effects of High Stakes School Achievement Awards: Evidence from a Randomized Trial,“ American Economic Review 99 (2009), 301-331.

Bartolucci, Cristian. “Gender Wage Gaps Reconsidered: A Structural Approach Using Matched Employer-Employee Data, “Journal of Human Resources 48:4 (2013), 998-1034.

Bettinger, Eric P. 2012. "Paying to Learn: The Effect of Financial Incentives on Elementary School Test Scores,“ Review of Economics \& Statistics 94:3 (2012), 686-698.

---------, and Bridget Terry Long, 2005. “Do Faculty Serve as Role Models? The Impact of Instructor Gender on Female Students, “ American Economic Review 95:2(2005): 152-157.

--------,, Torbjorn Haegeland,, and Mari Rege, 2014. "Home with Mom: The Effects of Stay-at-Home Parents on Children's Long-Run Educational Outcomes, “ Journal of Labor Economics 32:3 (2014), 443 - 467.

Cornwell, Christopher., David B. Mustard., and Jessica Van Parys, 2013. “Noncognitive Skills and the Gender Disparities in Test Scores and Teacher Assessments: Evidence from Primary School, “ Journal of Human Resources 48:1(2013), 236-264.

Dee, Thomas. "Teachers and the Gender Gaps in Student Achievement, "Journal of 
Human Resources, 42:3(2007), 528-554.

Ellison, Glenn., and Ashley Swanson. “The Gender Gap in Secondary School Mathematics at High Achievement Levels: Evidence from the American Mathematics Competition,” Journal of Economic Perspectives 24:2 (2010), 109-128.

Fortin, Nicole M., Philip Oreopoulos., and Shelley Phipps, 2015. "Leaving Boys Behind: Gender Disparities in High Academic Achievement, “ Journal of Human Resources 50:3 (2015), 549-579.

Fryer, Ronald. "Financial Incentives and Student Achievement: Evidence from Randomized Trials,” Quarterly Journal of Economics 126:4 (2011), 1755-1798.

Fryer, Ronald., and Steven Levitt. "An Empirical Analysis of the Gender Gap in Mathematics,” American Economic Journal: Applied Economics 2 (2010), 210-240. Fuchs, Thomas., and Ludger Woessmann. "What Accounts for International Differences in Student Performance? A Re-examination Using PISA Data," Empirical Economics 32:2-3 (2007), 433-462.

Gamboa,Luis Fernando and Fabio D Waltenberg "Inequality of Opportunity tor Educational Achievement in Latin America: Evidence From PISA 2006-2009," Economics of Education Review 31:5 (2012), 694-708.

Goldin, Claudia., Lawrence F. Katz., and Ilyana Kuziemko. "The Homecoming of American College Women: The Reversal of the College Gender Gap,” Journal of Economic Perspectives 20:4(2006), 133-156.

Gneezy, Uri., Aldo Rustichini. “Pay Enough or Don’t Pay At All,” Quarterly Journal of Economics 115 (2000), 791-810.

Guiso, Luigi, Ferdinando Monte, Paola Sapienza, and Luigi Zingales, “Culture, Gender, and Math,” Science 320:5880 (2008), 1164-1165.

Hanushek, Eric.A., Susanne Link, Ludger Woessmann. "Does School Autonomy Make Sense Everywhere? Panel Estimates From PISA,” Journal of Development Economics 104 (2013): 212- 232.

Hausmann, Ricardo., Laura D. Tyson., and Saadia Zahidi. The Global Gender Gap Report 2011. (2011) World Economic Forum. Geneva. http://www3.weforum.org/docs/WEF_GenderGap_Report_2011.pdf. (Accessed on September 20, 2015). 
Joensen, Juanna Schrøter and Helena Skyt Nielsen. "Is There A Causal Effect Of High

School Math on Labor Market Outcomes?,” Journal of Human Resources 44:1(2009), 171-198.

Kremer, Michael., Edward Miguel., and Rebecca Thornton, "Incentives to Learn,“ Review of Economics \& Statistics 91:3 (2009), 437-456.

Levine, P. B. and D. J. Zimmerman, “The Benefit of Additional High-School Math and Science Classes for Young Men and Women,” Journal of Business and Economic Statistics, 13:2 (1995), 137-149.

Leuven, Edwin., Hessel Oosterbeek., and Bas van der Klaauw, “The Effect of Financial Rewards on Students' Achievement: Evidence from a Randomized Experiment,“ Journal of the European Economic Association 8: 6 (2010), 1243-1265.

Niederle, Muriel., and Lise Versterlund. "Explaining the Gender Gap in Math Test Scores: The Role of Competition,” Journal of Economic Perspectives 24:2 (2010), 129-144.

Nielsen, Helena Skyt, and Beatrice Schindler Rangvid. “The Impact of Parents' Years Since Migration on Children's Academic Achievement,” IZA Journal of Migration 1:6 (2012), 1-23.

Neumark, David., and Rosella Gardecki. "Women Helping Women? Role Model and Mentoring Effects on Female Ph.D. Students in Economics,” Journal of Human Resources 33:1 (1998), 220-246.

Pope Devin G. and Justin R. Sydnor. "Geographic Variation in the Gender Differences in Test Scores,” Journal of Economic Perspectives 24:2 (2010), 95-108.

Rose, Heather. and Julian. R. Betts, “The Effect of High School Courses on Earnings,” Review of Economics \& Statistics 86:2 (2004), 497-513.

Sprietsma, Maresa. "Effect of Relative Age in The First Grade of Primary School on Long-Term Scholastic Results: International Comparative Evidence Using PISA 2003,” Education Economics 18:1 (2010), 1-32.

Stoet, Gijsbert., and David C. Geary, “Sex Differences in Mathematics and Reading Achievement are Inversely Related: Within- and Across- Nation Assessment of 10 Years of PISA Data, “ Plos One 8:3 (2013), 1-10. 
Table 1. Definitions of variables and basic statistics

\begin{tabular}{|c|c|c|c|}
\hline & Definition & Mean & $\begin{array}{l}\text { Standard } \\
\text { Deviation }\end{array}$ \\
\hline MATH & Students' mathematics test scores & 471.3 & 100.3 \\
\hline$S C I E N$ & Students' science test scores & 474.9 & 101.1 \\
\hline$R E A D$ & Students' reading test scores & 471.1 & 102.9 \\
\hline$W A G E \_F M$ & $\begin{array}{l}\text { Female/male wage rate in respondents' countries of } \\
\text { residence }\end{array}$ & 0.65 & 0.08 \\
\hline$G D P$ & $\begin{array}{l}\text { GDP per capita of students' country of residence (1000 } \\
\text { USD) }\end{array}$ & 53.1 & 41.4 \\
\hline FEMALE & $\begin{array}{l}\text { Takes the value } 1 \text { if students are female, and otherwise } \\
\text { is } 0\end{array}$ & 0.50 & 0.50 \\
\hline$L A T E$ & $\begin{array}{l}\text { Frequency of being late for school: } \\
1 \text { (None), } 2 \text { (Once or twice), } 3 \text { (Three or four times), } 4 \\
\text { (Five or more times) }\end{array}$ & 0.81 & 1.30 \\
\hline$S K I P$ & $\begin{array}{l}\text { Frequencies of skipping school: } \\
1 \text { (none), } 2 \text { (once or twice), } 3 \text { (three or four times), } 4 \text { (five } \\
\text { or more times) }\end{array}$ & 0.40 & 0.92 \\
\hline$S T U \_M A T H$ & Total minutes of class study on mathematics & 239.7 & 94.5 \\
\hline$S T U_{-} S C I E$ & Total minutes of class study on science & 225.5 & 144.5 \\
\hline$S T U_{-} R E A D$ & Total minutes of class study on reading & 234.1 & 92.8 \\
\hline$A G E$ & Respondent age & 15.7 & 0.29 \\
\hline$A R \_A G E$ & $\begin{array}{l}\text { Age at which respondents arrived in their current } \\
\text { country of residence }\end{array}$ & 6.4 & 4.5 \\
\hline WEALTH & Index of family wealth. & -0.16 & 1.05 \\
\hline$H \_F A T H$ & $\begin{array}{l}\text { Takes the value } 1 \text { if students live with their father, and } \\
\text { otherwise is } 0 .\end{array}$ & 0.85 & 0.35 \\
\hline H_MOTH & $\begin{array}{l}\text { Takes the value } 1 \text { if students live with their mother, } \\
\text { and otherwise is } 0 .\end{array}$ & 0.93 & 0.22 \\
\hline H_BROTH & $\begin{array}{l}\text { Takes the value } 1 \text { if students live with their brother, } \\
\text { and otherwise is } 0 .\end{array}$ & 0.62 & 0.48 \\
\hline H_SISTE & $\begin{array}{l}\text { Takes the value } 1 \text { if students live with their sister, and } \\
\text { otherwise is } 0 \text {. }\end{array}$ & 0.58 & 0.49 \\
\hline
\end{tabular}


Notes: WAGE_FM is gathered from Hausman et al. (2011). GDP is sourced from Penn World Table 8.1. (http://www.rug.nl/research/ggdc/data/pwt/pwt-8.1. accessed on September 20, 2015). Besides WAGE_FM and GDP, data is obtained from PISA 2012. Apart from $S T U_{-} R E A D, S T U_{-} S C I E$, and $S T U_{-} M A T H$, values are calculated based on the sample used in Table 3. Values for STU_READ, STU_SCIE, and STU_MATH are calculated based on the sample used in Table 4 . The index of family wealth (WEALTH) is based on the students' responses regarding whether they had the following at home: a room of their own, an Internet connection, a dishwasher (treated as a country-specific item), a DVD player, and three other country-specific items; as well as their responses regarding the number of cellular phones, televisions, computers, cars and rooms with a bath or shower. 
Table 2. Mean difference of test score between male and female students (sample of immigrants' children).

\begin{tabular}{lccc}
\hline & Boys & Girls & t-value \\
\hline MATH & 475 & 466 & $7.95^{* * *}$ \\
SCIEN & 473 & 475 & $-1.76^{*}$ \\
READ & 451 & 490 & $-34.5^{* * *}$ \\
\hline
\end{tabular}

Notes: * and *** indicate significance at the $10 \%, 5 \%$ and $1 \%$ levels, respectively. 
Table 3. SUR estimation

\begin{tabular}{|c|c|c|c|}
\hline & $\begin{array}{c}(1) \\
\operatorname{Ln}(M A T H)\end{array}$ & $\begin{array}{c}(2) \\
\operatorname{Ln}(S C I E)\end{array}$ & $\begin{array}{c}(3) \\
\operatorname{Ln}(R E A D)\end{array}$ \\
\hline $\begin{array}{l}\text { WAGE_FM } \\
F E M A L E\end{array}$ & $\begin{array}{l}0.13 * * * \\
(4.30)\end{array}$ & $\begin{array}{l}0.07 * * \\
(2.13)\end{array}$ & $\begin{array}{l}-0.01 \\
(-0.24)\end{array}$ \\
\hline$W A G E \_F M$ & $\begin{array}{l}0.11^{* * * *} \\
(5.86)\end{array}$ & $\begin{array}{l}0.03 \\
(1.48)\end{array}$ & $\begin{array}{l}0.11^{* * *} \\
(4.59)\end{array}$ \\
\hline$F E M A L E$ & $\begin{array}{l}-0.11^{* * *} \\
(-5.46)\end{array}$ & $\begin{array}{l}-0.04^{* *} \\
(-2.27)\end{array}$ & $\begin{array}{l}0.08^{* * * *} \\
(3.92)\end{array}$ \\
\hline $\operatorname{Ln}(G D P)$ & $\begin{array}{l}-0.01^{* * *} \\
(-7.26)\end{array}$ & $\begin{array}{l}-0.01 * * * \\
(-5.36)\end{array}$ & $\begin{array}{l}-0.01^{* *} \\
(-2.00)\end{array}$ \\
\hline$L A T E$ & $\begin{array}{l}-0.01^{* * *} \\
(-16.1)\end{array}$ & $\begin{array}{l}-0.01^{* * *} \\
(-14.6)\end{array}$ & $\begin{array}{l}-0.01^{* * * *} \\
(-14.5)\end{array}$ \\
\hline$S K I P$ & $\begin{array}{l}-0.02^{* * *} \\
(-13.6)\end{array}$ & $\begin{array}{l}-0.02^{* * * *} \\
(-12.8)\end{array}$ & $\begin{array}{l}-0.02^{* * * *} \\
(-14.5)\end{array}$ \\
\hline$A G E$ & $\begin{array}{l}0.02^{* * * *} \\
(5.27)\end{array}$ & $\begin{array}{l}0.01^{* * *} \\
(3.39)\end{array}$ & $\begin{array}{l}0.02^{* * * *} \\
(4.62)\end{array}$ \\
\hline$A R \_A G E$ & $\begin{array}{l}-0.0003 \\
(-1.08)\end{array}$ & $\begin{array}{l}-0.001^{* * *} \\
(-4.53)\end{array}$ & $\begin{array}{l}-0.002^{* * *} \\
(-7.15)\end{array}$ \\
\hline WEALTH & $\begin{array}{l}0.01^{* * *} \\
(9.03)\end{array}$ & $\begin{array}{l}0.01^{* * * *} \\
(8.10)\end{array}$ & $\begin{array}{l}0.01^{* * * *} \\
(10.5)\end{array}$ \\
\hline$H \_F A T H$ & $\begin{array}{l}0.01^{* * *} \\
(4.27)\end{array}$ & $\begin{array}{l}0.01 * * * * \\
(3.73)\end{array}$ & $\begin{array}{l}0.01^{* *} \\
(2.13)\end{array}$ \\
\hline H_MOTH & $\begin{array}{l}0.13^{* * *} \\
(22.0)\end{array}$ & $\begin{array}{l}0.12^{* * *} \\
(19.4)\end{array}$ & $\begin{array}{l}0.12^{* * *} \\
(20.2)\end{array}$ \\
\hline H_BROTH & $\begin{array}{l}-0.04^{* * *} \\
(-14.6)\end{array}$ & $\begin{array}{l}-0.04^{* * *} \\
(-13.6)\end{array}$ & $\begin{array}{l}-0.03^{* * *} \\
(-11.2)\end{array}$ \\
\hline H_SISTE & $\begin{array}{l}-0.03^{* * *} \\
(-12.0)\end{array}$ & $\begin{array}{l}-0.03^{* * *} \\
(-10.8)\end{array}$ & $\begin{array}{l}-0.02^{* * *} \\
(-9.65)\end{array}$ \\
\hline $\mathrm{R}$-square & 0.27 & 0.26 & 0.28 \\
\hline Observations & 19155 & 19155 & 19155 \\
\hline
\end{tabular}

Notes: Father's educational level, mother's educational level, and number of books in the home are included, but not reported. Numbers in parentheses are $\mathrm{z}^{-}$-values. ${ }^{*}, * *$ and $* * *$ indicate significance at the $10 \%, 5 \%$ and $1 \%$ levels, respectively. 
Table 4. SUR estimation

\begin{tabular}{|c|c|c|c|}
\hline & $\begin{array}{c}(1) \\
\operatorname{Ln}(M A T H)\end{array}$ & $\begin{array}{c}(2) \\
\operatorname{Ln}(S C I E)\end{array}$ & $\begin{array}{c}(3) \\
\operatorname{Ln}(R E A D)\end{array}$ \\
\hline $\begin{array}{l}\text { WAGE_FM } \\
F E M A L E\end{array}$ & $\begin{array}{l}0.12 * * * \\
(3.32)\end{array}$ & $\begin{array}{l}0.07^{*} \\
(1.71)\end{array}$ & $\begin{array}{l}-0.01 \\
(-0.20)\end{array}$ \\
\hline$W A G E \_F M$ & $\begin{array}{l}0.09 * * * \\
(3.35)\end{array}$ & $\begin{array}{l}0.03 \\
(1.16)\end{array}$ & $\begin{array}{l}0.09 * * * \\
(3.21)\end{array}$ \\
\hline$F E M A L E$ & $\begin{array}{l}-0.11^{* * *} \\
(-4.39)\end{array}$ & $\begin{array}{l}-0.05 * * \\
(-2.04)\end{array}$ & $\begin{array}{l}0.07 * * * \\
(2.87)\end{array}$ \\
\hline $\operatorname{Ln}(G D P)$ & $\begin{array}{l}-0.01^{*} \\
(-1.94)\end{array}$ & $\begin{array}{l}-0.003 \\
(-1.06)\end{array}$ & $\begin{array}{l}0.004 \\
(1.15)\end{array}$ \\
\hline$L A T E$ & $\begin{array}{l}-0.01^{* * * *} \\
(-11.3)\end{array}$ & $\begin{array}{l}-0.01^{* * * *} \\
(-10.4)\end{array}$ & $\begin{array}{l}-0.01 * * * \\
(-9.61)\end{array}$ \\
\hline$S K I P$ & $\begin{array}{l}-0.01^{* * *} \\
(-8.86)\end{array}$ & $\begin{array}{l}-0.01^{* * * *} \\
(-8.04)\end{array}$ & $\begin{array}{l}-0.02^{* * *} \\
(-9.57)\end{array}$ \\
\hline$S T U_{-} M A T H$ & $\begin{array}{l}0.05^{* * * *} \\
(5.72)\end{array}$ & & \\
\hline$S T U \_S C I E$ & & $\begin{array}{l}0.03^{* * *} \\
(5.60)\end{array}$ & \\
\hline$S T U_{-} R E A D$ & & & $\begin{array}{l}0.07 * * * \\
(7.21)\end{array}$ \\
\hline$A G E$ & $\begin{array}{l}0.02^{* * *} \\
(4.73)\end{array}$ & $\begin{array}{l}0.01 * * * \\
(3.16)\end{array}$ & $\begin{array}{l}0.02^{* * * *} \\
(3.74)\end{array}$ \\
\hline$A R \_A G E$ & $\begin{array}{l}-0.0009 * * \\
(-2.43)\end{array}$ & $\begin{array}{l}-0.001 * * * \\
(-4.58)\end{array}$ & $\begin{array}{l}-0.002^{* * *} \\
(-6.35)\end{array}$ \\
\hline WEALTH & $\begin{array}{l}0.01^{* * *} \\
(4.89)\end{array}$ & $\begin{array}{l}0.01^{* * *} \\
(5.50)\end{array}$ & $\begin{array}{l}0.01 * * * \\
(6.74)\end{array}$ \\
\hline$H \_F A T H$ & $\begin{array}{l}0.01^{* * * *} \\
(2.63)\end{array}$ & $\begin{array}{l}0.01^{* *} \\
(2.21)\end{array}$ & $\begin{array}{l}0.003 \\
(0.68)\end{array}$ \\
\hline H_MOTH & $\begin{array}{l}0.10^{* * * *} \\
(13.5)\end{array}$ & $\begin{array}{l}0.10^{* * *} \\
(12.4)\end{array}$ & $\begin{array}{l}0.10^{* * * *} \\
(12.8)\end{array}$ \\
\hline H_BROTH & $\begin{array}{l}-0.03^{* * *} \\
(-10.1)\end{array}$ & $\begin{array}{l}-0.03^{* * *} \\
(-9.30)\end{array}$ & $\begin{array}{l}-0.02^{* * *} \\
(-7.50)\end{array}$ \\
\hline H_SISTE & $\begin{array}{l}-0.03^{* * *} \\
(-9.16)\end{array}$ & $\begin{array}{l}-0.03^{* * *} \\
(-8.53)\end{array}$ & $\begin{array}{l}-0.02^{* * *} \\
(-7.20)\end{array}$ \\
\hline R-square & 0.28 & 0.27 & 0.28 \\
\hline Observations & 9998 & 9998 & 9998 \\
\hline
\end{tabular}

Notes: Father's educational level, mother's educational level, and number of books in the home are included, but not reported. Numbers in parentheses are $\mathrm{z}^{-}$values. ${ }^{*}, * *$ and $* * *$ indicate significance at the $10 \%, 5 \%$ and $1 \%$ levels, respectively. 
Table 5. SUR estimation for the sub-sample of Feyer and Levitt (2010)

\begin{tabular}{|c|c|c|c|c|}
\hline & & $\begin{array}{c}(1) \\
\operatorname{Ln}(M A T H)\end{array}$ & $\begin{array}{c}(2) \\
\operatorname{Ln}(S C I E) \\
\end{array}$ & $\begin{array}{c}(3) \\
\operatorname{Ln}(R E A D) \\
\end{array}$ \\
\hline \multirow{12}{*}{$\begin{array}{l}\text { Sub-sample A } \\
\text { Model of Table } 3\end{array}$} & $W A G E \_F M^{*}$ & $0.13 * *$ & 0.05 & -0.07 \\
\hline & $F E M A \bar{L} E$ & $(2.44)$ & $(0.85)$ & $(-1.27)$ \\
\hline & $W A G E \_F M$ & 0.04 & 0.05 & $0.26^{* * *}$ \\
\hline & & (1.19) & (1.34) & (5.90) \\
\hline & FEMALE & $-1.11^{* * *}$ & -0.04 & $0.13^{* * *}$ \\
\hline & & $(-3.17)$ & $(-1.06)$ & (3.31) \\
\hline & $L A T E$ & $-0.02 * * *$ & $-0.02^{* * *}$ & $-0.02^{* * * *}$ \\
\hline & & $(-11.2)$ & $(-9.94)$ & $(-10.8)$ \\
\hline & $S K I P$ & $-0.02^{* * *}$ & $-0.02 * * *$ & $-0.02 * * *$ \\
\hline & & $(-8.91)$ & $(-8.36)$ & $(-8.77)$ \\
\hline & R-square & 0.17 & 0.19 & 0.20 \\
\hline & Observations & 5169 & 5169 & 5169 \\
\hline \multirow{11}{*}{$\begin{array}{l}\text { Sub-sample } B \\
\text { Model of Table } 3\end{array}$} & $W A G E \_F M^{*}$ & $0.16^{* * *}$ & 0.06 & -0.07 \\
\hline & FEMALE & （3.74） & (1.30) & $(-1.54)$ \\
\hline & $W A G E \_F M$ & $0.14^{* * * *}$ & $0.13^{* * *}$ & $0.24^{* * *}$ \\
\hline & $F E M A I F$ & $(4.47)$ & (3.77) & $\begin{array}{l}(6.59) \\
0.12 * * * *\end{array}$ \\
\hline & FEMLALE & $(-4.48)$ & $\begin{array}{l}-0.04 \\
(-1.48)\end{array}$ & $\begin{array}{l}0.12 \\
(3.91)\end{array}$ \\
\hline & $L A T E$ & $-0.02 * * *$ & $-0.02^{* * *}$ & $-0.02^{* * * *}$ \\
\hline & & $(-13.2)$ & $(-11.7)$ & $(-11.8)$ \\
\hline & $S K I P$ & $-0.02^{* * *}$ & $-0.02^{* * *}$ & $-0.02^{* * *}$ \\
\hline & & $(-8.77)$ & $(-9.20)$ & $(-10.4)$ \\
\hline & R-square & 0.33 & 0.31 & 0.33 \\
\hline & Observations & 7346 & 7346 & 7346 \\
\hline
\end{tabular}

Notes: Sub-sample A consists of countries equivalent to the sample of "TIMSS-PISA overlap" in Table 7 of Fryer and Levitt (2010). Sub-sample B consists of countries included in PISA 2012 and overlapped with TIMSS 2003. Control variables used in Table 3 are included, but not reported. Numbers in parentheses are $\mathrm{z}^{-}$values. * ** and $* * *$ indicate significance at the $10 \%, 5 \%$ and $1 \%$ levels, respectively. 
Table 6. Multivariate Tobit estimation

\begin{tabular}{lll}
\hline & \multicolumn{1}{c}{$(1)$} & $(2)$ \\
& $L A T E$ & $S K I P$ \\
\hline WAGE_FM* & $-1.04^{*}$ & $-1.98^{* * *}$ \\
FEMALE & $(-1.93)$ & $(-2.90)$ \\
WAGE_FM & $1.35^{* * *}$ & $-5.24^{* * *}$ \\
& $(3.42)$ & $(-10.2)$ \\
FEMALE & 0.49 & $1.35^{* * *}$ \\
& $(1.39)$ & $(3.06)$ \\
Ln$(G D P)$ & $-0.61^{* * *}$ & $-0.33^{* * *}$ \\
& $(-14.8)$ & $(-6.33)$ \\
AGE & $0.25^{* * *}$ & 0.11 \\
& $(3.14)$ & $(1.10)$ \\
AR_AGE & -0.005 & $0.02^{* * *}$ \\
& $(-1.08)$ & $(3.24)$ \\
WEALTH & $0.14^{* * *}$ & $0.09^{* * *}$ \\
& $(5.81)$ & $(2.98)$ \\
H_FATH & $-0.49^{* * * *}$ & $-0.43^{* * *}$ \\
& $(-7.46)$ & $(-5.13)$ \\
H_MOTH & $-0.23^{* *}$ & -0.20 \\
& $(-2.33)$ & $(-1.59)$ \\
H_BROTH & $0.09^{*}$ & $0.13^{* *}$ \\
& $(1.96)$ & $(2.17)$ \\
H_SISTE & $0.09^{*}$ & $0.14^{* *}$ \\
& $(1.84)$ & $(2.24)$ \\
\hline Wald & \multicolumn{3}{c}{1116} \\
statistics & & \\
\hline Observations & & \\
& & \\
\hline
\end{tabular}

Notes: Father's educational level, mother's educational level, and number of books in the home are included, but not reported. Numbers in parentheses are $\mathrm{z}^{-}$values. ${ }^{*}, * *$ and $* * *$ indicate significance at the $10 \%, 5 \%$ and $1 \%$ levels, respectively. 
Table 7. Multivariate Tobit estimation for the sub-sample of Feyer and Levitt (2010)

\begin{tabular}{|c|c|c|c|}
\hline & & $\begin{array}{l}(1) \\
\text { LATE }\end{array}$ & $\begin{array}{l}(2) \\
S K I P\end{array}$ \\
\hline \multirow[t]{3}{*}{$\begin{array}{l}\text { Sub-sample A } \\
\text { Model of Table } 3\end{array}$} & $\begin{array}{l}\text { WAGE_FM* } \\
F E M A L E\end{array}$ & $\begin{array}{l}-0.65 \\
(-0.64)\end{array}$ & $\begin{array}{l}-2.92^{* *} \\
(-2.52)\end{array}$ \\
\hline & Wald statistics & 596 & 596 \\
\hline & Observations & 5169 & 5169 \\
\hline \multirow[t]{3}{*}{$\begin{array}{l}\text { Sub-sample } B \\
\text { Model of Table } 3\end{array}$} & $\begin{array}{l}\text { WAGE_FM* } \\
F E M A L E\end{array}$ & $\begin{array}{l}-1.34 \\
(-1.57)\end{array}$ & $\begin{array}{l}-2.97 * * * \\
(-3.02)\end{array}$ \\
\hline & Wald statistics & 705 & 705 \\
\hline & Observations & 7346 & 7346 \\
\hline
\end{tabular}

Notes: Sub-sample $A$ consists of countries equivalent to the sample of "TIMSS-PISA overlap" in Table 7 of Fryer and Levitt (2010). Sub-sample B consists of countries included in PISA 2012 and overlapped with TIMSS 2003. Control variables used in Table 6 are included, but not reported. Numbers in parentheses are $\mathrm{z}^{-}$values. ${ }^{*},{ }^{* *}$ and $* * *$ indicate significance at the $10 \%, 5 \%$ and $1 \%$ levels, respectively. 
Table 8. Decomposition of difference of female-male wage rate (WAGE_FM) on girl's test score.

\begin{tabular}{lcc}
\hline & $\begin{array}{c}\text { MATHEAD } \\
(\%)\end{array}$ & $\begin{array}{c}\text { SCIEN } \\
(\%)\end{array}$ \\
\hline Direct effect of a $1 \%$ decrease in WAGE_FM & 0.13 & 0.07 \\
Indirect effect of a $1 \%$ decrease in WAGE_FM through being late for school & 0.02 & 0.02 \\
Indirect effect of a $1 \%$ decrease in WAGE_FM through skipping school & 0.05 & 0.02 \\
Total effect of a $1 \%$ decrease in WAGE_FM & 0.20 \\
\hline
\end{tabular}

Notes: Values are calculated based on results of Table 3 and Table 6. 
Figure 1 (a). Relation between test scores in mathematics and female-male wage rate.

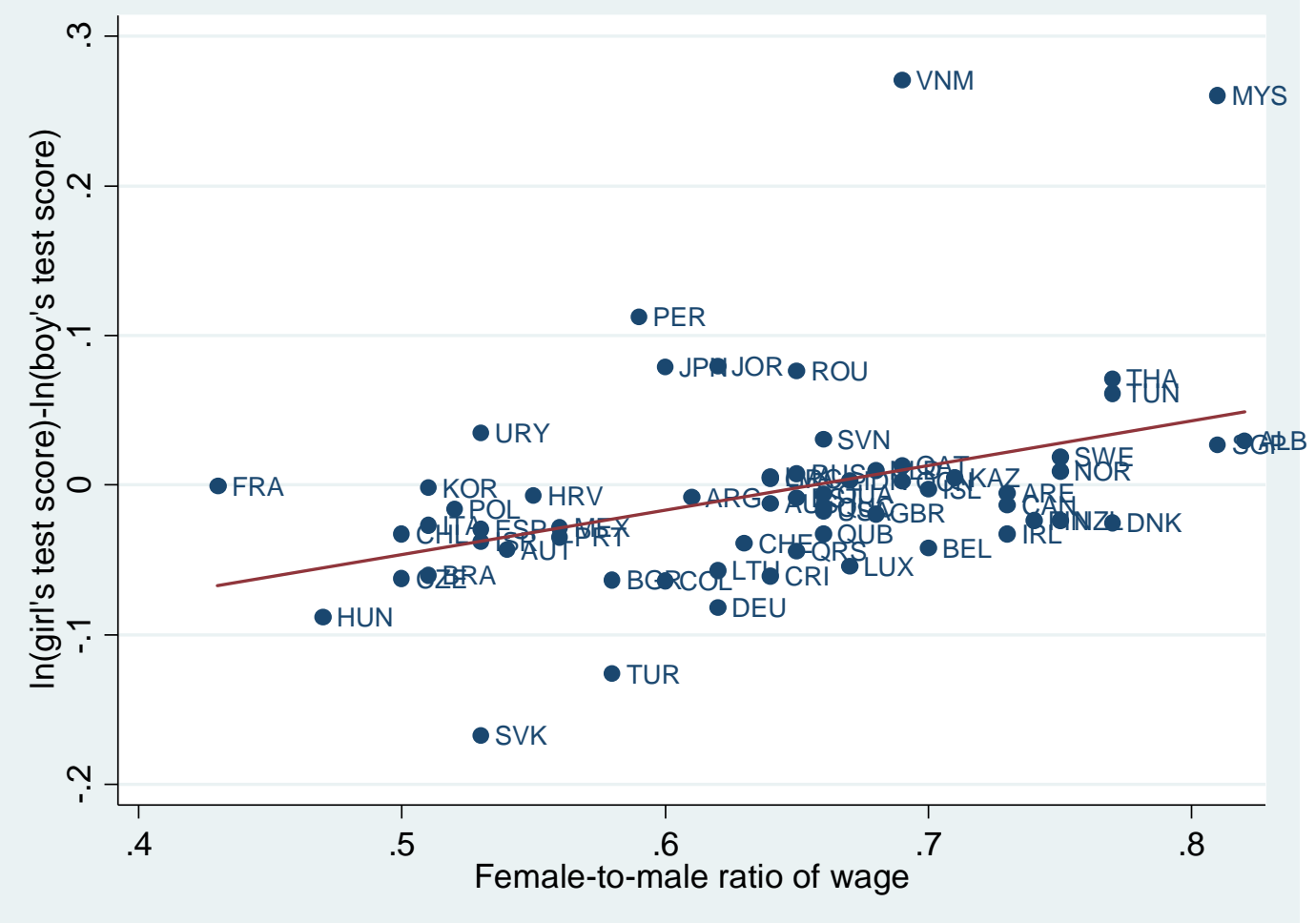

Note: Sample is restricted to sons and daughters of migrants. 
Figure 1 (b). Relation between test scores in science and female-male wage rate.

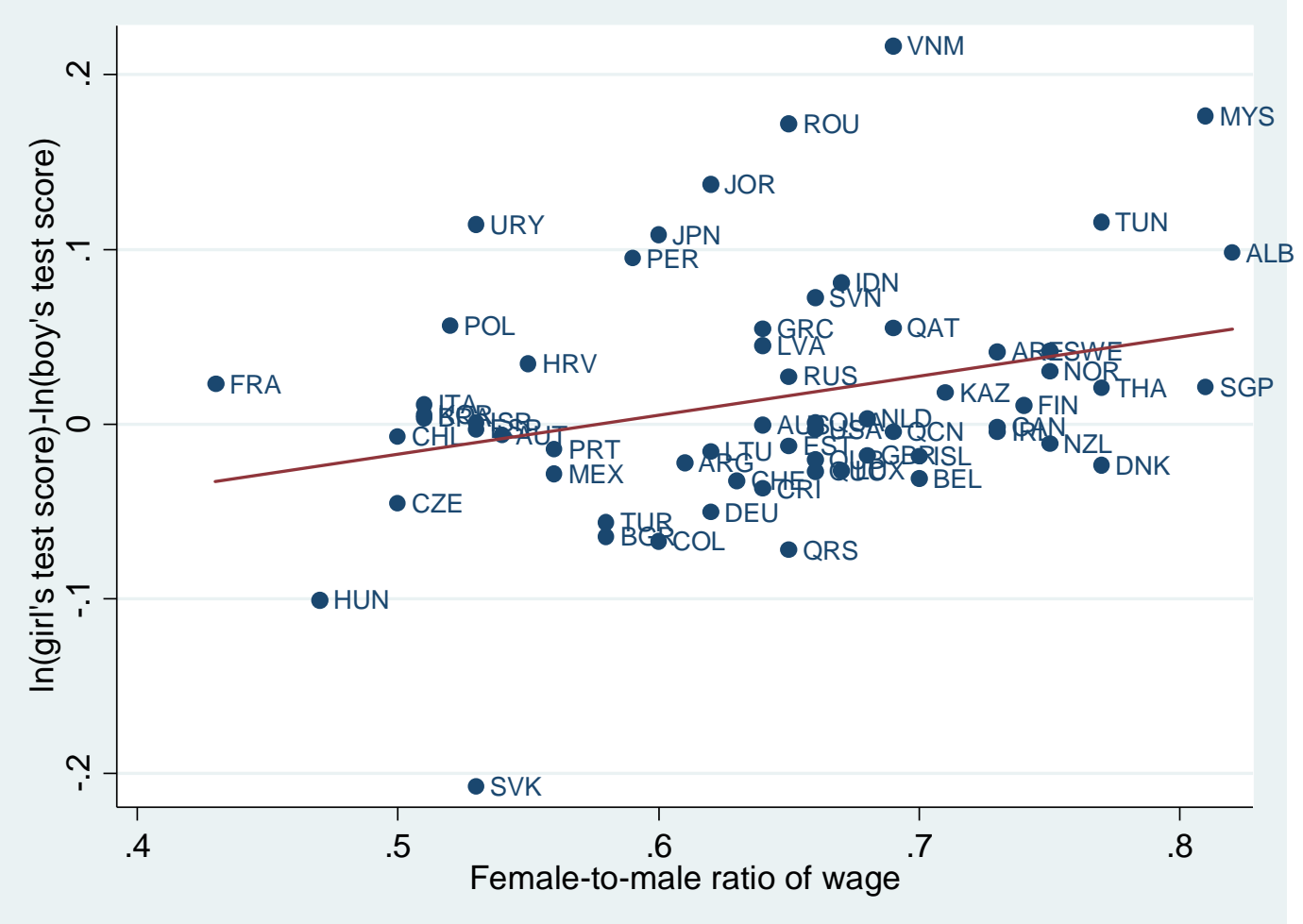

Note: Sample is restricted to migrants' sons and daughters.

Figure 1 (c). Relation between test scores in reading and female-male wage rate. 


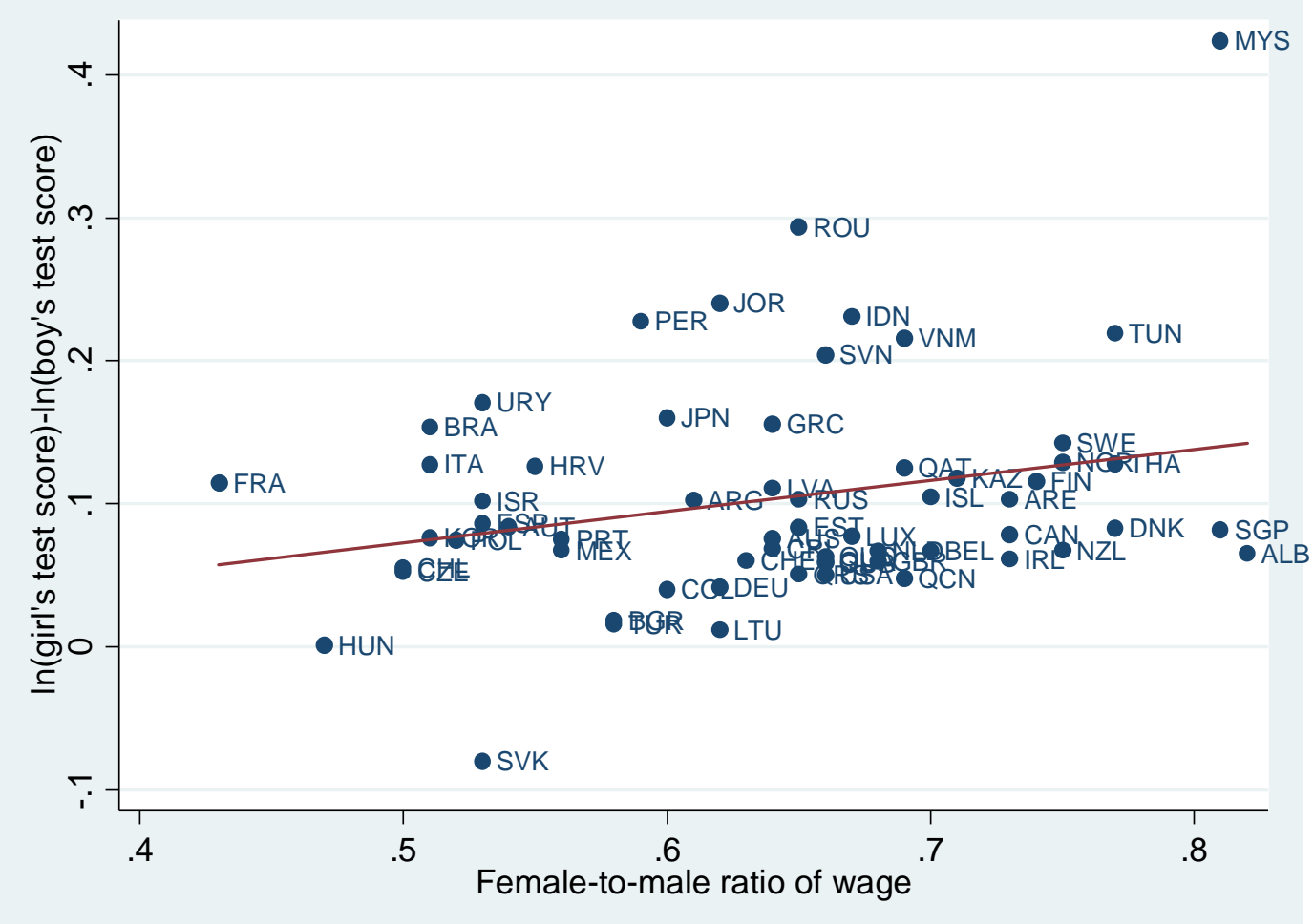

Note: Sample is restricted to migrants' sons and daughters. 